\title{
Opinion
}

\section{Inaccuracies and useless debats associated with the use of secondary references}

\author{
Albert Mudry', Robert Ruben ${ }^{2}$, Wolfgang Pirsig ${ }^{3}$
}

We are really disappointed by the saga born after the publication of "Peripheral facial palsy in the past: contributions from Avicenna, Nicolaus Friedrich and Charles Bell", written by Resende and Weber ${ }^{1}$. The controversy began with the statement that "Charles Bell [...] himself had right peripheral facial paralysis". This hypothesis generated a letter to the editor by Korteweg et al. ${ }^{2}$ which clearly demonstrates that this affirmation was not based on original documents, but on interpretation of secondary sources, and that it was erroneous. The authors' reply introduced new doubtful pictorial arguments not mentioned in the first publication. Once again, Korteweg et al. ${ }^{3}$ replied in proving that these new arguments were based on invalid suppositions and that they can't be used to support the fact that Bell had himself a facial paralysis. This time, the authors' reply added some inadequate "personal" comments, which have nothing to do with a constructive and scholarly discussion. Such kind of saga is no more acceptable in a well educated exchange of knowledge. The historian's task is to assemble a sufficient number of facts, based on valid original documents; history takes shape from these and can then be discussed and interpreted. Theoretical reflection is sometimes harmful, because it can introduce erroneous speculation. Original Bell's publications demonstrate that Bell never describes that he was suffering himself of a facial palsy and no existing portraits confirm this hypothesis.

Resende and Weber support the affirmation of Korteweg et al. that "we should always check the primary sources concerned", but they do not apply it in their writings. How can they discuss the contributions of Avicenna, Nicolaus Friedreich and Charles Bell without mentioning their original contributions? Their article contains inaccuracies such as the following sentence concerning Charles Bell: "His first case of peripheral facial palsy was published in 1821, and his most important paper was published in 1828". Two debatable points are found here: the text published in 1821 effectively contains a case of a man which "had the trunk of the respiratory nerve of the face injured by suppuration", but not a case of idiopathic peripheral facial palsy later named after Bell ${ }^{4}$. Its major concerns is the description of the anatomy of the "respiratory nerve of the face", i.e. the facial nerve, and the results obtained after sectioning the nerve in animals. It is not in 1828 but in $1827^{5}$ that Bell published his main text dealing with the description of a case of peripheral facial palsy which bears his name. Thus the first case of a Bell's palsy was described by Bell in 1827 and not in 1821. These are typical examples of inaccuracies generated with the use of secondary references as often found in the medical literature ${ }^{6}$. Further, Resende and Weber used mainly Jongkees's publication as indisputable reference ${ }^{7}$. Once again this publication contains inaccuracies, the first disputed one being the interpretation of the original text of Bell. The German translation made by Jongkees is incomplete, because Jongkees did not mention the first part of the original Bell's text which clearly explains that it was a professor named Roux who was suffering from a right facial palsy and not Bell himself, thus leading Jongkees to wrongly think that Bell had himself a facial paralysis. If we closer look Jongkees' text we can find other inaccuracies, for example when he wrote that Falloppio: "schrieb nur ein Buch" "Observationes anatomicae" (wrote only one book)". This is wrong: Falloppio also wrote at least two other books: Lectiones de partibus similaribus corporis humani. His accessere diversorum animalium sceletorum explicationes iconibus illustratae. Norimberg: Gerlachius, 1575, and Opera, quae adhuc extant, omnia. Venetiis: Valgrisius, 1584. Even more, Jongkees mentions in reference three Bell's articles published in the Philosophical Transactions of the Royal Society of London. The first one has wrong pages, the second one does not exist and the third one has also wrong pages ${ }^{8}$ ! Jonckees also did not mention the exact reference of 1827 Bell's text. How 
can Resende and Weber blindly trust professor Jongkees' text without checking the original documents used by Jongkees? At least, concerning Friedreich, they referred to Bird's publication ${ }^{9}$ and the erroneous date of 1798 . Interestingly, this paper does not contain the original Latin dissertation of Friedreich already published in $1797^{10}$ but only an English summary and review published three years later ${ }^{11}$ and extracted from a German report published in $1798^{12}$; once again, confusion and no original source!

If we closer look Resende and Weber's text, more inaccuracies are found. Some pictures are not correctly described such as Fig 1D which is a Roman vase not found in a tomb from Ancient Greece, but in a tomb in Austria. Fig $2 \mathrm{C}$ represent two masks, without grimaces, of the Middle Ages from Switzerland with facial paralysis, and the sculpture in Fig 4D is not made by the painter Lucas van Leyden (1493-1533) but was carved by the sculptor Nicolas Gerhaert van Leyden (1430-1473), who for a time worked in Strassburg, where this statue can be found today. It represents a central, and not a peripheral facial paralysis, because of the presence of clear frontal folds, and there is no sign of parotidis. We can keep on and certainly find more inaccuracies such as the Fig $7 \mathrm{C}$ of Duchenne which does not represent a facial palsy but the electrical stimulation of the different muscles of the face or the incorrect spelling of the different referenced articles published by Kindler. We can also discuss the title, in the way that some figures represent cases of facial paralysis, probably of central origin, because the frontal fold are clearly visible such as Figs 1C, 4D (already discussed), and 6D. The correct title would be without the word "peripheral".

Finally, the personal context of an author has nothing to do with the pertinence and quality of its work. Fortunately in the Netherlands, as well as in Brazil, and in all countries, contrasts exist: they make the ground and the wealth of our society. You can be young and make great contributions to our specialty: Domenico Cotugno was 24 years old when he published his famous De Aquaeductibus auris humanae internae in $1760^{13}$, and Alphonso Corti was 29 years old when he described the structures of the inner ear which bears his name ${ }^{14}$. The number of publications of an author is not an absolute guarantee that he or she makes no error. How many medico-historical articles have been published by Resende and Weber? No paradox exists between young, unknown author and well known professors: there are all scientists who can bring new insight in our specialty; this is the strength of medicine. History of medicine is fascinating in many ways. It is not such kind of inadequate and personalized saga which brings us pleasure and fortune in practicing the history of our specialty. It is of note that Korteweg's co-author, Van de Graaf, is also young, and more importantly, has written more than 30 medico-historical articles and book chapters, mainly about the history of facial palsy.

In conclusion, only new clearly documented and proved facts can corroborate the statement that "Charles Bell [...] himself had a right peripheral facial palsy". If Resende and Weber can bring these new indisputable facts, they will be agreed by the medico-historical literature. Until now, we must accept that Charles Bell was not affected by peripheral facial palsy himself.

\section{REFERENCES}

1. Resende LA, Weber S. Peripheral facial palsy in the past: contributions from Avicenna, Nicolaus Friedrich and Charles Bell. Arq Neuropsiquiatr 2008;66:765-769.

2. Korteweg SF, Van de Graaf RC, Werker PM. About the right facial palsy of Charles Bell: was Sir Charles Bell himself really affected by facial palsy? Comment on 'peripheral facial palsy in the past. Contributions from Avicenna, Nicolaus Friedrich and Charles Bell'. Arq Neuropsiquiatr 2009;67:783; author reply 783-784

3. Korteweg S, Van de Graaf R, Werker P. Sir Charles Bell was not affected by facial palsy himself? Arq Neuropsiquiatr 2010;68:321-322; author reply 322.

4. Bell C. On the nerves; giving an account of some experiments on their structure and functions, which lead to a new arrangement of the system. Philos Trans Roy Soc 1821;111:398-424.

5. Bell C. Appendix to the papers on the nerves. London: Longman, Rees, Orme, Brown, \& Green, 1827:68-72.

6. Mudry A. Never trust secondary references: examples from the early history of myringotomy and grommets. Int J Pediatr Otorhinolaryngol 2008; 72:1651-1656.

7. Jongkees LBW. Bemerkungen zur Geschichte der Fazialischirurgie. HNO 1979;27:325-333.

8. Bell C. On the nerves of the face; being a second paper on that subject. Philos Trans Roy Soc 1929;119:317-330.

9. Bird TD. Nicolaus A. Friedrich's description of peripheral facial nerve paralysis in 1798. J Neurol Neurosurg Psychiatry 1979;42:56-58.

10. Friedrich N. De paralysis musculorum faciei rheumatica. Wirceburgi: Rienner, 1797.

11. Anonymous. Ueber die rheumatische Lähmung der Gesichtsmuskeln. J Erfindungen (Gotha) 1798;7:83-95.

12. Anonymous. De paralysis musculorum faciei rheumatica. Programma quo ad orationem, die $18^{\circ}$ Novembris 1797, invitat Nicolaus Friedreich. Annals of Medicine (1800) (Edinburgh) 1801;5:214-226.

13. Cotugno D. De aquaeductibus auris humanae internae. Neapoli: Somoniana, 1760.

14. Corti A. Recherches sur l'organe de l'ouïe des mammifères. Première partie: limaçon. Z Wiss Zool 1851;3:109-169. 